\title{
LIBRARY OF PHILOSOPHY
}

As may be seen from the original programme printed in Erdmann's History of Philosophy under the date 1890, the Library of Philosophy was designed as a contribution to the History of Modern Philosophy under the heads: first of different Schools of Thought-Sensationalist, Realist, Idealist, Intuitivist; secondly of different Subjects-Psychology, Ethics, Esthetics, Political Philosophy, Theology. While much had been done in England in tracing the course of evolution in nature, history, economics, morals and religion, little had been done in tracing the development of thought on these subjects. Yet "the evolution of opinion is part of the whole evolution."

By the co-operation of different writers in carrying out this plan it was hoped that a thoroughness and completeness of treatment, otherwise unattainable, might be secured. It was believed also that from writers mainly British and American fuller consideration of English Philosophy than it had hitherto received might be looked for. In the earlier series of books containing, among others, Bosanquet's History of Asthetics, Pfleiderer's Rational Theology since Kant, Albee's History of English Utilitarianism, Bonar's Philosophy and Political Economy, Brett's History of Psychology, Ritchie's Natural Rights, these objects were to a large extent effected.

In the meantime original work of a high order was being produced both in England and America by such writers as Bradley, Stout, Bertrand Russell, Baldwin, Urban, Montague and others, and a new interest in foreign works, German, French and Italian, which had either become classical or were attracting public attention, had developed. The scope of the Library thus became extended into something more inter- 
national, and it is entering on the fifth decade of its existence in the hope that it may contribute in this highest field of thought to that Intellectual Co-operation which is one of the most significant objects of the League of Nations and kindred organizations.

GENERAL EDITOR

November 1, 1931. 


\section{LIBRARY OF PHILOSOPHY}

GENERAL EDITOR:

PROFESSOR J. H. MUIRHEAD, LL.D.

ANALYTIC PSYCHOLOGY By Prof. G. F. Stout. Two Vols. 5th Impression.

ATTENTION By Prof. W. B. Pillsbury. 2nd Impression.

HISTORY OF ÆSTHETIC By B. Bosanquet. 5th Impression. $4^{\text {th }}$ Edition.

HISTORY OF ENGLISH UTILITARIANISM By Prof. E. Albee.

HISTORY OF PHILOSOPHY By J. E. Erdmann.

Vol. I. Ancient and Mediaval. 5th Impression.

Vol. II. MODERn. 6th Impression.

Vol. III. Since Hegel. 7 th Impression.

HISTORY OF PSYCHOLOGY By Prof. G. S. Brett.

Vol. I. ANcient aNi Patristic.

Vol. II. Mediaval and Early Modern Period.

Vol. III. MOdern Psychology.

MATTER AND MEMORY By Henri Bergson. Translated by N. M. Paul and W. S. Palmer. 4th Impression.

NATURAL RIGHTS Jy D. G. Ritchie. 3rd Edition.

PHILOSOPHY AND POLITICAL ECONOMY By Dr. J. Bonar. $4^{t h}$ Impression.

DEVELOPMENT OF THEOLOGY SINCE KANT By $O$. Pfleiderer.

THE PHENOMENOLOGY OF MIND By G. W. F. Hegel. Translated by Dr. F. B. Baillie. 2 nd Edition.

TIME AND FREE WILL By Prof. Henri Bergson. Translated by $F$. $L$. Pogson. 5th Impression.

VALUATION: THE THEORY OF VALUE By Prof. W. M. Urban.

THE PSYCHOLOGY OF THE RELIGIOUS LIFE By Prof. G. M. Stratton. 2nd Edition.

THE GREAT PROBLEMS By Bernardino Varisco. Translated by Prof. R. C. Lodge.

KNOW THYSELF By Bernardino Varisco. Translated by Dr. Guglielmo Salvadori.

ELEMENTS OF FOLK PSYCHOLOGY By W. Wundt. Translated by Prof. Edward L. Schaub. 3rd Impression.

ELEMENTS OF CONSTRUCTIVE PHILOSOPHY By Prof. J. S. Mackenzie. 2nd Impression.

SOCIAL PURPOSE By Dr. H. J. W. Hetherington and Prof. J. H. Muirhead. 2nd Impression. 


\section{LIBRARY OF PHILOSOPHY-contd.}

INTRODUCTION TO MATHEMATICAL PHILOSOPHY By Bertrand Russell, F.R.S. $3^{\text {rd Impression. }}$

GOD AND PERSONALITy (Gifford Lectures) By Prof. Clement C. J. Webb. (Part I.) 2nd Impression.

DIVINE PERSONALITY AND HUMAN LIFE (GIFFORD LECTURES) By Prof. Clement C. J. Webb. (Part II.) 2nd Impression.

MODERN PHILOSOPHY By Guido de Ruggiero. Translated by $A$. Howard Hannay and R. G. Collingwood.

THE ANALYSIS OF MIND By Bertrand Russell, F.R.S. 3rd Impression.

DIALOGUES ON METAPHYSICS By Nicolas Malebranche. Translatcd by Morris Ginsberg.

INDIAN PHILOSOPHY By Prof. S. Radhakrishnan. 2nd Edition. Tro Vols.

CONTEMPORARY BRITISH PHILOSOPHY Edited by Prof. J. H. Muirhead. Tiwo Vols.

The ways of KNowing: or The Methods of Philosophy By Prof. W. P. Montague. 2nd Impression.

A THEORY OF DIRECT REALISM; ANd tile Rel.ation of REAlism to IDEalism By J. E. Turner.

THE GOOD WILL: A STUDY IN THE COHERENCE THEORY OF GOODNESS By H. J. Paton.

FUNDAMENTAL PROBLEMS OF LIFE: AN ESSAY ON CITIZENSHIP AS PURSUIT OF VALUES By Prof. J. S. Mackenzie.

THE INTELLIGIBLE WORLD: METAPHYSICS AND VALUE By Prof. W. M. Urban.

CONTEMPORARY AMERICAN PHILOSOPHY Edited by Prof. George P. Adams and Prof. Wm. Pepperell Montague. Two Vols.

HEGEL'S SCIENCE OF LOGIC Translated by W. H. Folnston and L. G. Struthers. Twoo Vols.

IDENTITY AND REALITY By Emile Meyerson. Translated by Kate Loezenberg.

MORAL SENSE By James Bonar.

COLERIDGE AS PHILOSOPHER By Prof. J. H. Muirhead.

IDEAS: GENERAL INTRODUCTION TO PURE PHENOMENOLOGY By Edmund Husserl. Translated by W. R. Boyce Gibson.

THE PLATONIC TRADITION IN ANGLO-SAXON PHILOSOPHY By Prof. J. H. Muirhead. 

Library of Philosophy

EDITED BY J. H. MUIRHEAD, LL.D.

ETHICS 


\section{VOL. ONE: MORAL PHENOMENA}

After pointing out the errors involved in ethical naturalism, the author proceeds to refute Kant's teaching that the moral law, because discerned a priori, issues from Reason and is a sclflegislation of the rational will. Against this view Plato's position is upheld, that all values and the Ought constitute an objective, absolute realm of essences, which man discovers a priori, but which no more emanate from Reason than do the principles of mathematics and logic.

\section{VOL. TWO: MORAL VALUES}

The author presents all values as forming a complex and, as yet, imperfectly known system. The actualization of the non-moral and of the elementary moral values is a necessary condition for the actualization of the higher. On this account the rudimentary values have a prior claim. The author then gives in outline the main features of the chief virtues, and shows that the moral disposition required in any exigency is always a specific synthesis of various and often conflicting virtues.

\section{VOL. THREE: MORAL FREEDOM}

This volume is devoted to the thesis that morality is possible only in a world determined throughout, mentally as well as physically, by the law of cause and effect. But as organic life, although dependent upon mechanical laws, cannot be explained by them, so moral life cannot be explained by physiological and psychological processes. Responsibility, imputability, and the sense of guilt imply that man is free to do otherwise than he actually does. If man is not free in this sense, then his consciousness of responsibility and of guilt is a delusion. He is in fact determined neither by the moral law nor by the laws of nature, but is self-determined. 



\title{
E T H I C S
}

by

\section{NIGOLAI HARTMANN}

Professor of Philosophy, University of Berlin

\author{
TRANSLATED BY \\ STANTON COIT \\ (Authorized Version)
}

\author{
VOLUME III \\ MORAL FREEDOM
}

LONDON: GEORGE ALLEN \& UNWIN LTD NEW YORK: THE MACMILLAN COMPANY 
The German original, "Ethik," was published in 1926

FIRST PUBLISHED IN ENGLISH 1932

All rights reserved

PRINTED IN GREAT BRITAIN BY

UNWIN BROTHERS LTD., WOKING 